УДК 130.2:7.01:77

https://orcid.org/0000-0003-1523-2341

\title{
ІСТОРИКО-ПІЗНАВАЛЬНЕ КІНО ЯК ФЕНОМЕН ПЕРІОДУ НЕЗАЛЕЖНОСТІ УКРАЇНИ
}

\author{
O.I. Орлов, аспірант кафедри теоретичної і практичної філософії \\ філософського факультету Харківського національного університету \\ імені В.Н. Каразіна
}

В статті пропонується огляд історико - пізнавального кіно в українській кінематографії періоду незалежності. Акиентується увага не лише на тематичному розмаїтті стрічок, а й на філософській, герменевтичній, психоаналітичній можливості й потребі їх трунтовного вивчення. Так, зокрема, хронікодокументальним та науковопопулярним кінофільмам Украӥни періоду незалежності властивий акиент на історичному освітленні держави та українського народу, сочіальним проблемам, осмисленню правового поля буття українців.

Ключові слова: історико - пізнавальне кіно, національна ідентичність, герменевтика, інтерпретація, кінопрокат, реконструкція.

Актуальність проблеми. Сьогодні мистецтво кінематографії - це потреба в презентації себе в духовній культурі сучасного світу: пошук місця українського в кінематографії світу, визначення тих рис, за якими наше кіно пізнається, аналіз сприйняття українцями стрічок свого виробництва та того, як сприймають українське кіно за кордоном. Сьогодні є іноземні кінострічки про Україну - як нас бачать інші країни (ми очима інших). Прикладом може слугувати фільм Єжи Гофмана «Україна. Становлення нації» (2008), в якому західному суспільству запропоновано розгорнутий образ минулого й сучасного України. Кіно виступає не лише як інструмент соціалізації, а й осмислення власної національної самобутності та унікальності, що можна позначити як пошук свого «національного обличчя». У прокаті, на кінофестивалях - кінопродукція $€$ частиною презентації національної ідентичності. Національна ідентичність - об’єднує персональну й соціальну складові, шлях самопізнання - в співвідношенні себе 3 Іншим, наявність якого допомагає людини чи нації усвідомлювати себе, співвідносити 3 оточуючим світом (психоаналітичне співвідношення Я / суб’єкт - Інший). Власний спосіб самореалізації, притаманний кожній нації, свою ідентичність 
виявляє на всіх рівнях - від побутового до політичного.

Ступінь дослідження проблеми. Простежуючи динамічні процеси у вітчизняному кінематографі доби незалежності, дослідники враховують соціальні, культурні та економічні чинники впливу, звертають увагу переважно на ті картини, які вважають характерними або симптоматичними для певної фази розвитку кінопроцесу, а також визначають особливості творів. Деякі аспекти проблеми, порушеної у статті, розглядали Л. Брюховецька, Л. Зінченко, І. Зубавіна, С. Марченко, О. Рутковський.

Мета статті - розглянути та проаналізувати історико-пізнавальне кіно як феномен періоду незалежності України.

Зміни, що були зумовлені в період становлення та розвитку незалежної України, привели до розвитку суспільних наук та мистецтва, появилися нові підходи і методи осягнення й відображення дійсності. На початок 90-х років НКУ - Київнаукфільм дістає бюджетне фінансування і випускає за рік 136 назв (144 серії) науково-пізнавальних картин, з них 12 фільмів циклу «Золоте стремено» з історії української армії, 8 - 3 історії українського права, 12 - 3 історії лікарської справи в Україні, 104 фільми - серіал науково-пізнавальних стрічок «Невідома Україна. Нариси нашої історії». Станом на 2000-ні роки українське кіно помалу почало привертати до себе серйозний інтерес європейців. 32007 р. стає цілком реально просувати вітчизняне кіно у світі $[3$, c. 226].

До симптоматики означеного періоду слід віднести зацікавлення такими сферами життя та історії, що кілька десятиліть 3 різних причин залишалися поза увагою кінематографістів. Відбувалося відкриття безлічі «ареалів», які тривалий час видавалися «білими плямами». А також кінематографічному. В перші роки незалежності український кінематограф занурюється в історію. Причини цього зрозумілі - прагнення усвідомлення історичної справедливості, новий погляд на події української історії («пострадянська рефлексія» [3, с. 56]). Гуманітарний напрямок та історія як наука в радянські часи були майже вилучені, саме цим пояснюється така жага 
до історичних питань. Змінилося ставлення до історії, що проявилося в масі досліджень, відкритті архівів стосовно голодомору, голокосту, Другої світової, визвольної боротьби УПА, репресій. «Виробництво науковопізнавальних картин про історію, як правило, здійснюється паралельно 3 осмисленням цієї історії» [5, с. 204]. За роки незалежності в історії українського кіно виникло явище - новий спосіб дослідження історії засобами науково-популярного кіно. Важливим прикладом $є$ кінематографічний погляд на історію Сергія Буковського, який простежується в його фільмі « Війна. Український рахунок».

Причина появи фільму «Війна. Український рахунок», за словами самого Сергія Буковського, та, що тема війни 1941-1945 років була надзвичайно розтиражована і популярна саме в радянські часи, а потім кудись зникла, ніби розчинилася у повітрі. Щоправда окремі фільми з'являлися у 1990-х роках, за часів реабілітації дисидентів, націоналістів, проте не було, на думку режисера, серйозного, збалансованого аналізу тих жахливих подій. Тому Сергій Буковський вирішив спокійно і толерантно, 3 розсудливістю розповісти про супротивників. Фільм містив різні сторінки історії тих років, від оборони Києва і до визволення України, зокрема йшлося про облогу Севастополя, а також про історію Української Повстанської Армії, дивізію «Галичина». Таким різнобарвним постає контекст цього кінематографічного полотна, яке вплітає у своє тло різноманітні картини тогочасного суспільства (певна річ, радянського) [4, с. 166-167].

Специфіка роботи над цією серійною картиною полягала в тому, що увага приділялася однаковою мірою всім героям, а також не було, так би мовити, «залізного» погляду і сценарію, а в ході зйомок не обійшлося без відкриттів. Варто додати, що героями фільму стали не представники генералітету чи старшого офіцерського складу, а звичайні рядові солдати та сержанти. Вони воювали в окопах і тому їм надали слово, і це, як зазначає Буковський, принципово [4, 167].

Завдання цієї документальної стрічки український режисер вбачав не 
в тому, щоб зруйнувати стереотипи, як часто говорять у пресі, оскільки, на його думку, ніхто не надавав зрештою права бути «прокурором, суддею i робити якісь висновки чи руйнувати міфи», а саме в тому, щоб розповісти наступним поколінням, як це відбувалося насправді, та, зрештою, повернути почуття власної гідності тим, кому навішували ярлики «бандерівець» тощо. Фільм здобув Шевченківську премію, що є найвищою нагородою-визнанням нашої держави.

Наступним етапом роботи Сергія Буковського над складною українською темою став фільм «Назви своє ім'я», присвячений трагедії українських євреїв - Голокосту. Розпочався він за ініціативи американського кінорежисера Стівена Спілберга, який відрядив в Україну продюсера Марка Едвардса для пошуків українського документаліста, який би створив кінокартину на цю тему. Інститут відеоісторії та формування Фонду Шоа при Університеті Південної Каліфорнії став основним джерелом, чи архівом інтерв’ю постраждалих, зібраних голлівудським партнером майбутньої кінострічки свідчень, i це дало поштовх до початку проекту. Сергій Буковський, невдовзі після запрошення Спілберга, вирушив до ЛосАнджелеса на студію Universal. Таким чином, основою фільму стали свідчення очевидців та учасників тих подій.

Сам режисер говорив, що картина виявилася значно важчою навіть за 9-серійний фільм про війну. Адже матеріал надзвичайно складний. Не можна було просто переглядати інтерв’ю, а потім вільно відволікатися на іншу справу i 3 легкістю забувати про роботу. Люди в знімальній групі надзвичайно зблизилися, дбали не про кіно, а про архів, щоб зберегти найцінніші свідчення. Тож спроби «нав’язати» режисерові інше бачення зазнавали краху. Характерним є те, що Сергій Буковський спеціально ніби обриває кожну історію, не даючи цілком завершеної картини життя людини. Але цей засіб, як він пояснює, є зумисним, оскільки це було бажання показати, як з окремих життєвих шляхів складається доля єдиного народу. 
Історична тематика зосереджена на періодах Гетьманщини (робота Р. Плахова-Модестова «Ще як ми були козаками»); радянської влади, Другої світової («Війна. Український рахунок» С. Буковського, 2002; фільм О. Роднянського «Прощавай, СРСР», дві частини 1992 та 1994 рр.); викритті злочинів радянського режиму («Пейзаж після мору» Ю. Терещенко, 2005); голокост («Бабин яр: правда про трагедію», 1990, реж. В. Георгієнка та О. Шлаєна); екранне осмислення трагедії Чорнобилю («Чорнобиль. Тризна», реж. Р. Сергієнко, 1994); документальні біографії діячів культури та політики (кінотрилогія А. Мікульського «Я камінь з Божої пращі» про О. Ольжича; проект каналу «Інтер» «Великі українці» - 2008 р.[7]. Визнаними майстрами документального жанру в Україні є Степан Коваль, Вікто Шкурін, Юрій Терещенко, Сергій Буковський. Документальне кіно тісно пов'язане 3 Київнаукфільмом. Володимир Штомолоха, ставши керівником в 1993 р., реорганізує Київнаукфільм в Національну кінематику України і розробляє масштабний проект для популяризації історії - 108 короткометражних фільмів «Невідома Україна» - просвітницьке висвітлення історії від прадавніх часів до здобуття країною незалежності.

Документалістика хоч i пов'язана, перш за все, 3 історичними джерелами, та важливе місце в ній займає філософська інтерпретація дійсності. Про це свідчить поява нового жанру - документальної драми, де поруч 3 реконструкцією подій подаються спроби осягнення сенсу буття та інтерпретації тієї чи іншої події. Сьогодні пріоритети українського документального кіно - в реалізації інформативної, аксіологічної, соціологізуючої функції. Йдеться, насамперед, про формування інформаційних потоків, скерованих на формування національної ідентичності, невирішених соціальних проблем, духовних аспектів буття українців.

Доля вітчизняних митців щільно переплетена 3 долею народу, вони оперують не тільки нещодавно відкритими для доступу архівними матеріалами, а й життєвим досвідом власних родин. Культуролог С. Марченко наводить такий приклад: «У 1987 р. режисер Микола Лактіонов- 
Стезенко починає роботу над повнометражною стрічкою «33-й, свідчення очевидців». Після отримання Україною незалежності центр уваги кінематографістів переноситься насамперед на трагічні наслідки антиукраїнської політики Імперії: - тема голодомору, що стала об’єктом кінематографічної уваги спочатку за межами України, у канадській діаспорі, за часів перебудови досліджується вітчизняними майстрами екрану, а у добу незалежності набуває поглибленого розвитку. Це постановчо-хронікальний «Голод 33» (1991) Олеся Янчука; художньо-публіцистична картина-реквієм жертвам голодомору 1933-го року в Україні «Пієта» (1993) Миколи Мащенка; документальна стрічка «Великий злам» (1993) Сергія Лисенка; «Час скорботи і пам’яті» (1993, режисер О. Косіков); тетралогія «Українська ніч 1933-го» (1994, режисер В. Георгієнко); - відлуння воєнних зіткнень та кровопролить різних часів, серед яких тема національно-визвольної боротьби 1941-1954 рр. у Західній Україні, суворо заборонена за радянської пори: спомини про УПА «Проводжала мати сина» (УПА) /1993/ та «Спогад про УПА» («Розрита могила») /1994/ Леоніда Мужука. Національно-визвольному руху присвячено стрічки «Тверді мелодії» (1993) Георгія Давиденка та Олександра Давиденка; «Чия правда, чия кривда» (1993) Аркадія Микульського; - наслідкам репресій присвячено фільми «Табірний пил» (1990, Георгій Давиденко), «Сталінський синдром» (1990, Роман Ширман); На ювілейному вечорі до 80-річчя режисера (Будинок кіно, 16 лютого 2009 р.) він з гіркотою згадав, що цей твір - відбиток його особистої родинної трагедії: від голоду загинули батьки, в яких забрали весь хліб» [5 с. 193]. У низці фільмів, присвячених голоду 1933 р. («Ой горе, це ж гості до мене» П. Фаренюка, «Свіча Джеймса Мейсона» Н. Сущевої, «Пейзаж після мору» Ю. Терещенка та ін.), кінематографісти мовою екрана звертаються до національної пам'яті, щоб повернути їй цілісність, порушену десятиліттями замовчування історичної правди.

У доробку кіностудії «Контакт» мозаїка української ідентичності складається з повернутих із радянського забуття імен: митрополита Андрія 
Шептицького («Богові й людям», 2000), художника Михайла Бойчука («Бойчук і бойчукізм», 2001), письменників Миколи Хвильового («Думки проти течії», 2001), Петра Григоренка («Експертиза... Страта божевіллям», 1999), Володимира Винниченка («Кому повідаю печаль мою?», 1999), Віктора Некрасова («Паризька Одіссея», 2000), патріарха Йосифа Сліпого («Патріарх. Життя Йосифа Сліпого», 2002), також - з імен творців сучасної національної культури: художньої династії Якутовичів («Якутовичі», 2007), театрального й кіноактора Миколи Гринька («Доторк... Прикосновение...», 2003), головного диригента Київської опери Стефана Турчака («Диригент Стефан Турчак», 2004), а ще - 3 портретів політиків, які визначають долю України («Леонід Кравчук. Обрання долі», «Володимир Щербицький. На перехресті думок і поглядів»). У цій праці зусилля «Контакту» не були поодинокими.

Слід зазначити, що виробництво науково - пізнавальних картин про історію здійснюється паралельно з осмисленням цієї історії. Феномен цього кіно в тому, що воно «пробило асфальт»[5, С. 206]. Сьогодні пріоритети українського кіно даної тематики - в реалізації інформативної, аксіологічної, соціологізуючої функції. В сучасному мистецтві, кінематографії, літературі засобами досліджень психоаналізу, герменевтики, феноменології постають особистість та соціум XXI століття.

\section{Список використаних джерел}

1. Брюховецька О.В. Ідентифікація в кіно:психоаналітичний підхід // Національний Університет «КиєвоМогилянська академія». Наукові записки. - Т. 22.: У трьох частинах. Частина 1. Гуманітарні науки. / О. В. Брюховецька - К.: КМАкадемія, 2003.

2. В Україні знімають патріотичний серіал про Нацгвардію // Корреспондент.net, 4 грудня 2014, 17:51. режим доступу: http://ua.korrespondent.net/ukraine/3451886-vukraini-znimauit-patriotychnyi-serial-pronatshvardiui

3. Зубавіна І. Б. Кінематограф незалежної України: тенденції, фільми, постаті / І. Б. Зубавіна. - К. : ІПСМ АМУ; ФЕНІКС, 2017. - 296 с.

4. Зінченко Л. Сергій Буковський на новий кінематографічний погляд на історію / Л. Зінченко // Українське кіно від 1960-х до сьогодні. Проблема виживання : [зб. ст.] / [упоряд. Л. Брюховецька]. - К. : Задруга, 2010. С. $165-175$.

5. Марченко С. Історико-пізнавальне кіно як феномен незалежної України // Українське кіно від 1960-х до сьогодні. Проблема виживання. - К.: Задруга, 2010. - С. 191-208.

6. Марченко С. Історія як зображення: матеріал та образ. Аспекти кінотворення історії України : [електронний ресурс] / Сергій Марченко. - Режим доступу: http://www.telekritika.ua/daidzhest/2008-12$13 / 42639$.

7. Міщенко М.М. документальний кінематограф України: між історичною реконструкцією та філософським 
осмисленням. - Вісник ХНУ імені В.Н. Каразіна. - № 1116. Серія «Філософія. Філософські перипетії». 2014.

8. Філатов А. Катерина Копилова:кінематограф - це найпростіший шлях до душі людини / Антон Філатов // Українська культура. - 2013. - № 6. - С. 53-55.

References

1. Briukhovetska O.V. Identyfikatsiia v kino:psykhoanalitychnyi pidkhid // Natsionalnyi Universytet «KyievoMohylianska akademiia». Naukovi zapysky. - T. 22.: U trokh chastynakh. Chastyna 1. Humanitarni nauky. / O. V. Briukhovetska - K.: KMAkademiia, 2003.

2. V Ukraini znimaiut patriotychnyi serial pro Natshvardiiu // Korrespondent.net, 4 hrudnia 2014, 17:51. - rezhym dostupu: http:/ua.korrespondent.net/ukraine/3451886-vukraini-znimauit-patriotychnyi-serial-pro-natshvardiui

3. Zubavina I. B. Kinematohraf nezalezhnoi Ukrainy: tendentsii, filmy, postati / I. B. Zubavina. - K. : IPSM AMU; FENIKS, 2017. - $296 \mathrm{~s}$.

4. Zinchenko L. Serhii Bukovskyi na novyi kinematohrafichnyi pohliad na istoriiu / L. Zinchenko // Ukrainske kino vid 1960-kh do sohodni. Problema vyzhyvannia : [zb. st.] / [uporiad. L. Briukhovetska]. - K. : Zadruha, 2010. - S. 165-175.

5. Marchenko S. Istoryko-piznavalne kino yak fenomen nezalezhnoi Ukrainy // Ukrainske kino vid 1960-kh do sohodni. Problema vyzhyvannia. - K.: Zadruha, 2010. - S. 191-208.

6. Marchenko S. Istoriia yak zobrazhennia: material ta obraz. Aspekty kinotvorennia istorii Ukrainy : [elektronnyi resurs] / Serhii Marchenko. - Rezhym dostupu: http://www.telekritika.ua/daidzhest/2008-12-13/42639.

7. Mishchenko M.M. dokumentalnyi kinematohraf Ukrainy: mizh istorychnoiu rekonstruktsiieiu ta filosofskym osmyslenniam. - Visnyk KhNU imeni V. N. Karazina. - № 1116. Seriia «Filosofiia. Filosofski perypetii». - 2014.

8. Filatov A. Kateryna Kopylova:kinematohraf - tse naiprostishyi shliakh do dushi liudyny / Anton Filatov // Ukrainska kultura. - 2013. - № 6. - S. 53-55.

\section{ИСТОРИКО-ПОЗНАВАТЕЛЬНОЕ КИНО КАК ФЕНОМЕН ПЕРИОДА НЕЗАВИСИМОСТИ УКРАИНЫ}

\section{О.И. Орлов}

В статье предлагается обзор историко-познавательного кино в украинской кинематографии периода независимости. Акцентируется внимание не только на тематическом разнообразии кинолент, а и на философской, герменевтической, психоаналитической возможности и потребности их основательного изучения. Отмечено, что хронико-документальным и научно-популярным кинофильмам Украины периода независимости характерный акцент на историческом освещении государства и украинского народа, социальным проблемам, осмыслению правового поля бытия украинцев.

Ключевые слова: историко-познавательное кино, национальная идентичность, герменевтика, интерпретация, кинопрокат, реконструкция.

\section{HISTORICAL-COGNITIVE CINEMA AS A PHENOMENON OF THE PERIOD OF INDEPENDENT UKRAINE}

\section{O. Orlov}

This article offers a survey of the historical-cognitive cinema in Ukrainian cinematography during the independence period. The author focuses on both thematic diversity of films, and philosophical, hermeneutic, psychoanalytic possibilities and demand of their thorough study. Indicated that, chronicle-documentary and popular science films of Ukraine during the independence period inherent mapping of historical development of the state and the Ukrainian people, social problems, and understanding the legal framework of Ukrainians.

The article deals with the features of cinematography among other means of mass communication in the context of its influence on the mass consciousness.

The tendencies of Ukrainian cinema as a distinctive genre in the field of directorial and acting art are analyzed. The process of formation of the national school of cinema during the Independence period is shown, and its activity with the work of directors of the previous Soviet period in the 
history of Ukrainian cinema art is compared. The contribution of Ukrainian actors of the theater and cinema, artists, scriptwriters and directors to the development of massive cinema playing during the independence period.

As an example of the development of Ukrainian cinema, the trends of the historical cognitive cinema during the Independence period were analyzed, on the basis of which the features of the country's exhibit in elite circles were determined.

Key words: historical - cognitive cinema, national identity, hermeneutics, interpretation, film rental, reconstruction. 